\title{
Druggable Targets in Pancreatic Adenocarcinoma
}

\author{
Stefania Nobilii,* , Renato Tassi ${ }^{2, *}$, Ida Landini², Gabriele Perrone ${ }^{1}$, Cristina Napoli ${ }^{1}$, \\ \& Enrico Mini ${ }^{2, * *}$ \\ ${ }^{1}$ Department of Health Sciences, University of Florence, Firenze, Italy ${ }^{2}$ Department of Experimental and Clinical \\ Medicine, University of Florence, Firenze, Italy \\ *These authors contributed equally to this work \\ **Address all correspondence to: Enrico Mini, Department of Experimental and Clinical Medicine, University of Florence, viale Pieraccini, \\ 6 - 50139 Firenze, Italy; Tel: +39-055-2758368; Email: enrico.mini@unifi.it
}

\begin{abstract}
Pancreatic ductal adenocarcinoma (PDAC) is a leading cause of cancer-related death worldwide. It is often diagnosed at an advanced or metastatic stage and results of the approved systemic therapies are discouraging, making PDAC one of most lethal cancers in Western countries. In recent years, a better comprehension of PDAC unique biology has disclosed new potential targets for therapeutic interventions. Meanwhile, the development of conjugated agents, small molecules, antibodies, and immunoagents has opened therapeutic opportunities for drugs able to exert therapeutic effects on druggable targets of PDAC biology. Despite some failures, this approach is bringing meaningful results from bench to bedside, and more efficacious therapeutic opportunities may become available for PDAC treatment. In this review, we discuss the main hallmarks of PDAC biology as its microenvironment, cancerdriving proliferative pathways, growth suppression loops, and how PDAC evades immune system surveillance, as well as molecular aspects of each feature. The main preclinical and clinical results of each targeted intervention are also presented considering its biological rationale. Ongoing clinical trials provide evidence of the effectiveness of this approach and promising results in the treatment of PDAC.
\end{abstract}

KEY WORDS: PDAC hallmarks, PDAC target therapy, PDAC immunotherapy

ABBREVIATIONS: CPAA: pancreatic carcinoma-associated antigen; TLA-4: cytotoxic T-lymphocyte antigen 4; DHH: desert hedgehog; ECM: extracellular matrix; EMT: epithelial-to-mesenchymal transition; FOLFIRINOX: 5-fluorouracil/leucovorin, oxaliplatin, irinotecan; GAP: GTPase-activating protein; GEF: guanine nucleotide exchange factor; GEP: gene expression profile; GLI: glioma-associated oncogene; GM-CSF: granulocyte-macrophage colony-stimulating factor; GWAS: genome-wide analysis study; HA: hyaluronan acid; HGFR: hepatocyte growth factor receptor; Hh: Hedgehog; IGF: insulin-like growth factor; IHH: Indian hedgehog; ILK: integrin-linked kinase; JNK: c-Jun N-terminal kinase; K-RAS: Kristen rat sarcoma; LODER: local drug eluter; MMP: matrix metalloproteinase; MoAbs: monoclonal antibodies; Nab-paclitaxel: nanoparticle albumin-bound paclitaxel; ODSH: 2-O,3-O desulfated heparin; OS: overall survival; PARP: poly-ADP-ribose polymerase; PD-1: programmed death 1 protein; PDAC: pancreatic ductal adenocarcinoma; PEGPH20: PEGylated hyaluronidase; PFS: progression-free survival; PI3K: phosphatidylinositol 3-kinase; PIP3: phosphatidyl-inositol 3,4,5 triphosphate; PSC: pancreatic stallate cell; PTCH: patched; PTEN: tensin homolog deleted on chromosome 10 phosphatase; SHH: sonic hedgehog; siRNA: small interfering RNA; SMO: smoothened; SPARC: secreted protein acidic and rich in cysteine; TGF- $\boldsymbol{\beta}$ : transforming growth factor $\beta$; TKI: tyrosine kinase inhibitor; VEGF: vascular endothelial growth factor

\section{INTRODUCTION}

Pancreatic ductal adenocarcinoma (PDAC) and its variants, usually called pancreatic cancer, is the most common malignancy of the pancreas, accounting for $\sim 85-90 \%$ of pancreatic neoplasms. ${ }^{1}$ PDAC is the sixth and the eight leading cause of cancer-related deaths worldwide and in Europe, respectively. ${ }^{2,3}$
Only $25 \%$ of newly diagnosed PDAC patients are eligible for potentially curative surgery because most patients are diagnosed at advanced/metastatic stages of disease. However, despite adjuvant treatment, the 5-year survival rate of these patients is only $\sim 20 \%{ }^{4}$

Cytotoxic chemotherapy represents the standard of care of inoperable and metastatic PDAC. Nonetheless, PDAC is usually resistant to systemic therapies, 
and the 5-year survival rate is $\sim 7 \% .{ }^{5}$ Currently, the approved treatment regimens for systemic disease, such as the combination of 5-fluorouracil/leucovorin, oxaliplatin, irinotecan (FOLFIRINOX regimen), ${ }^{6}$ gemcitabine, and nanoparticle albumin-bound paclitaxel (nab-paclitaxel) $)^{7}$ or other gemcitabine-based combinations ${ }^{8}$ offer only a few months survival benefit over gemcitabine monotherapy that have represented the standard treatment approach since the late 1990 s. $^{9}$

In past decades, relevant advances have been made in understanding PDAC genetic and nongenetic risk factors, and more recently, in comprehending PDAC molecular biology.

Risk factors such as smoking, diabetes mellitus, nonhereditary chronic pancreatitis, and obesity have been associated with the development of pancreatic tumors. It is also estimated that $5-10 \%$ of pancreatic cancers have an inherited component, although in most of cases the genetic basis for familial aggregation has not been identified. ${ }^{10}$ No effective screening tool for PDAC is available to detect asymptomatic premalignant or early malignant tumors. In addition, no protective agent against PDAC has been identified. Although there is a consensus regarding the value of a screening test in the case of inherited predisposition for PDAC, there is no agreement on the most effective screening tool or on the optimal interval between examinations. ${ }^{11,12}$

As far as PDAC molecular biology is concerned, a pivotal study covering this issue was authored by Jones et al, ${ }^{13}$ who showed that PDAC is driven by alterations of multiple genes involved in cell cycle regulation, metabolism, and DNA repair. In particular, the genome-wide analysis of 24 PDAC samples identified an average of 63 genetic alterations, mostly point mutations in 12 key cellular signaling pathways (i.e., K-RAS, SMAD4, JNK, integrin, Wnt/Notch, Hedgehog, small GTPase signaling) and processes (i.e., control of $\mathrm{G} 1 / \mathrm{S}$ phase transition, apoptosis, DNA damage control, invasion, hemophilic cell adhesion). Each pathway was altered in $67-100 \%$ of the tumors studied.

A more recent study by Biankin et al. showed that driver mutations in PDAC are very scarce $(\leq 6-7)$, suggesting that such a small number is pos- sibly sufficient for PDAC tumorigenesis. ${ }^{14}$ Through whole-exome sequencing of 99 PDAC samples, they evidenced a high number of nonsilent mutations and copy number variations (2016 and 1628, respectively). Apart from known mutations (e.g., in $K-R A S, T P 53, C D K N 2 A$, and SMAD4 genes), most of the others have rarely been reported. ${ }^{14}$

Today, it is recognized that activating point mutations of the $K-R A S$ oncogene are the most common genomic alterations in PDAC, their frequency being $>90 \%$. Frequencies of mutations in most commonly altered tumor suppressor genes range from $60-70 \%$ of TP53 to 5-10\% of MLL1, MLL2, KDM6A. Mutations in other tumor suppressor genes such as $C D K N 2 A$, which is involved in the G1 cell cycle arrest pathway, are found in $>50 \%$ of PDACs. Mutations in SMAD 4 and $T G F-\beta R 1 / 2$, which are involved in the TGF- $\beta$ pathway, are found in $\sim 50 \%$ of PDACs. Mutations in ARIDIA, ARIDIB and SMARCA1, which are involved in the nucleosome remodeling, are found in $10-15 \%$ of PDACs and, finally, mutations in ATM and $B R C A 2$, which are involved in DNA damage response, are found in $\sim 10 \%$ of PDACs. ${ }^{15,16}$

Other relevant information has been derived from the mutational analysis of tumors and corresponding metastases. ${ }^{17,18}$ Results of two relevant studies showed that genomic instability persists after cancer dissemination, ${ }^{17}$ that genetic heterogeneity of metastases reflects the heterogeneity within the primary carcinoma, and that a very long time frame occurs between tumor initiation and progression. ${ }^{18}$ The need of driver mutations for the development of seeding metastasis, in addition to those required for primary tumors, has also been shown. ${ }^{17}$

The knowledge of the signaling pathways, processes, and driver mutations involved in PDAC tumorigenesis and metastasis may be useful for the identification of molecular biomarkers predictive of treatment efficacy as well as a rational approach to treatment.

To date, only a few studies have analyzed correlations between PDAC molecular biology and response to treatment according, for instance, to genome-wide analysis (GWAS) or gene expression profile (GEP) approaches. However, Collisson et al., ${ }^{19}$ using primary PDAC explants and human pan- 
creatic cancer cell lines, identified gene signatures predictive of drug responses. Their results showed three distinct molecular subtypes of PDAC according to their respective gene expression patterns: classic, quasimesenchymal, and exocrine like. The classic subtype expressed high levels of adhesion associated and epithelial genes (e.g., $A G R 2$ and $S 100 P B P$ ), the quasimesenchymal subtype expressed high levels of mesenchyme associated genes (e.g., TWIST1 and S100A2), and the exocrine-like subtype had high expression of genes involved in digestion (e.g., REG3A (PAP) and PRSS1). Subtypes differed in response to chemotherapy (i.e., gemcitabine and erlotinib) in human PDAC cell lines of a known subtype. The quasimesenchymal subtype lines were, on average, more sensitive to gemcitabine than the classical subtype, whereas erlotinib was more effective in the classical subtype cell lines. Because the classical PDAC lines were relatively more dependent on K-RAS than quasimesenchymal subtype lines, the authors suggested that $K-R A S$ mutation status is an imperfect predictor of sensitivity to EGFRtargeted therapy in PDAC and implies that cancer cells dependent on mutant $K-R A S$ still employ EGFR to some extent.

Overall, these findings suggest that the PDAC subtype specificity could be exploited to select anticancer drugs to maximize their efficacy. This goal has become mandatory considering that, despite improved understanding of the biology of PDAC, 5-year survival rates are dismal, as previously discussed..$^{5}$ Actually, cytotoxic drugs are not able to adequately target and exploit PDAC's unique biology.

Today, only some of the above discussed altered events can be considered "druggable" due to multiple reasons (e.g., difficulties in recognizing driver from passenger mutations, difficulties in restoring tumor suppressor function, and difficulties in identifying targetable sites in macromolecular complexes due to protein-protein interactions). ${ }^{20}$ However, several hallmarks have been proposed for various types of cancer, including PDAC. These comprise biological capabilities acquired during multistep development of tumors such as tumor microenvironment, sustaining proliferative signaling, inducing angiogenesis, evading growth suppression, and avoiding immune destruction. ${ }^{21}$ Some of these hallmarks depend on tumor-specific genetic defects that may render cancer cells vulnerable to synthetic lethality approaches that can finally kill tumor cells while sparing normal cells. ${ }^{22}$ In this review, we discuss targets involved in PDAC hallmarks and pathways. Some of these have already been successfully targeted in other neoplasms. We also focus on drugs currently under investigation in the most advanced phases of clinical trials in PDAC patients.

\section{TUMOR MICROENVIROMENT}

In recent years, tumors have been increasingly recognized as having a heterogeneous microenvironment of cellular elements that include specialized types of cells, neoplastic cells, and extracellular matrix (i.e., tumor microenvironment). ${ }^{21}$ Cancer itself constructs a tumor microenvironment during the course of multistep tumorigenesis to enable tumor growth and spread of disease. This complex structure is composed by different elements that cross talk and dynamically erect and remodel the extracellular matrix. Cancer stem cells represent the foundation of the disease; they initiate tumors and drive its progression carrying genetic mutations that promote cancer itself. Cancer stem cells are functionally defined by their ability to seed new tumors upon inoculation. Endothelial cells form the tumor-associated vasculature fundamental to the nutritional and oxygen support of neoplastic elements. Pericytes are a specialized mesenchymal cells that surround the endothelium, providing it with a paracrine and mechanical support. Fibroblasts and myofibroblasts create a structural foundation supporting the epithelial tissue and, therefore, the neoplastic epithelial elements. Immune inflammatory cells belong to the immune system and operate with tumor-antagonizing and tumor-promoting functions. ${ }^{23}$

The tumor microenvironment plays a major role in PDAC biology; thus, it represents a target of interest for preclinical and clinical research in PDAC, and it has been shown to affect both tumor growth and therapeutic response. ${ }^{24,25} \mathrm{PDAC}$ is characterized by a highly dense stroma consisting of extracellular matrix components, inflammatory cells, and 
proliferating myofibroblasts also called pancreatic stellate cells (PSCs). The latter are responsible for the production of thick extracellular matrix (ECM) of type I collagen, proteoglycans, and glycosaminoglycans as hyaluronan acid. ${ }^{26}$ PSCs also deliver growth factors that mainly contribute to proliferation and survival of neoplastic elements. ${ }^{27,28}$ In addition, the pancreatic tumor stroma contributes to leaky intratumoral vasculature, reduced blood flow (therefore an hypoxic state), and high interstitial pressure that may impair drug delivery. ${ }^{29,30}$ In PDAC, tumor stroma are characterized by an excessive proliferation of fibrotic tissue called desmoplastic reaction that provides a protumorigenic environment for PDAC cells and contributes to the selection of more aggressive clones. ${ }^{31}$ The main tumor stroma targets that have been investigated in PDAC are secreted protein acidic and rich in cysteine (SPARC), the hedgehog $(\mathrm{Hh})$ pathway, and hyaluronan acid (HA).

\section{A. Secreted Protein Acidic and Rich in Cysteine}

Osteonectin, also known as SPARC, is an ECM glycoprotein that has been shown to play a crucial role in tissue homeostasis. ${ }^{32}$ By binding to multiple structural components as collagen, interstitial proteins as albumin, and controlling matrix metalloproteinase (MMP) activity, SPARC regulates the ECM organization and turnover. ${ }^{33}$ Moreover, SPARC has a role in angiogenesis through direct binding of vascular endothelial growth factor (VEGF), thus preventing interactions with its receptor or through inhibitory effects on endothelial cells, and through regulatory effects on matrix cells in the production of proangiogenic factors. ${ }^{34}$ Finally, SPARC and transforming growth factor $\beta$ (TGF $\beta$ ), as well as other growth factors, have complex mutual regulatory effects that result in matrix production and cellular growth (see section III.C.). ${ }^{35}$

A role of SPARC in PDAC was theorized following molecular profiling studies of PDAC and immunostaining analysis of primary tumors in which SPARC was overexpressed compared with normal tissue. ${ }^{36}$ Moreover, the most frequent pattern is a cancer-cell-negative/stromal-fibroblast-positive
SPARC expression and has been associated with a significantly shorter median overall survival (OS) (15 months versus 30 months, $p>0.001$ ), irrespective of tumor size, grade, margin status, lymph nodes, and patient age ${ }^{37}$ Although SPARC expression is a marker of poor prognosis because it has a high affinity for albumin, it has been suggested that elevated SPARC expression may enable albumin-bound drugs (i.e., nab-paclitaxel) to be retained in SPARC-positive areas. ${ }^{38}$ This was the biological rationale for the intratumoral delivery of nab-paclitaxel in PDAC.

In a phase 1-2 trial, nab-paclitaxel was used in combination with gemcitabine. The median OS of patients with high SPARC was 17.8 months versus 8.1 months of those with low SPARC expression $(p=.043) .{ }^{39}$ Given these positive results, nab-paclitaxel has been evaluated in a phase 3 trial. $^{7}$ The primary endpoint was reached showing the superiority of the combination on gemcitabine alone with a median OS of 8.5 versus 6.7 months $(\mathrm{HR}=0.72$, $\mathrm{p}<0.001$ ), respectively, leading to the approval of nab-paclitaxel in PDAC. A subsequent analysis of this phase 3 clinical trial showed that the activity of nab-paclitaxel was not related to SPARC expression. ${ }^{40}$ SPARC levels were neither prognostic for survival nor predictive of response, making it premature for any treatment decisions depending on SPARC expression in PDAC.

\section{B. HEDGEHOG SIGNALING PATHWAY}

The Hh pathway consists of three secreted ligands (sonic hedgehog (SHH), Indian hedgehog (IHH) and desert hedgehog $(\mathrm{DHH})$, a negative regulatory receptor, patched $(\mathrm{PTCH})$, the positive regulatory protein smoothened (SMO) and the glioma-associated oncogene (GLI) transcription factors (GLII, GLI2, and GLI3). ${ }^{41}$

Although $\mathrm{Hh}$ is silenced in normal tissue after embryogenesis ${ }^{42}$ in various cancers such as PDAC it is aberrantly reactivated. ${ }^{43}$ Hedgehog $(\mathrm{Hh})$ signaling occurs following the binding of Hh ligands to the PTCH receptor. This interaction leads to the inhibition of the PTCH receptor and, consequently, to the release of the G-protein-coupled receptor SMO. This 
results in a cascade of events and in the translocation of the Gli transcription factor to the nucleus. The latter induces the expression of various context-specific genes, such as those encoding the D-type cyclins, $c-M Y C, B C L 2$, and SNAIL, which regulate cellular differentiation, proliferation, and survival and are typically dysregulated in cancer cells. ${ }^{44}$

Two distinct ligand-dependent activation pathways are supposed to underlie Hh activation: an autocrine pathway and a paracrine pathway. In the autocrine pathway, Shh transcription is directly increased and proliferation of pancreatic cancer cells is accelerated via its overexpression. ${ }^{1}$ In the paracrine pathway, tumor-associated stroma cells secrete tumor-growth factors through stromal Hh signaling activation or, alternatively, they produce Shh, which stimulates in turn the Hh signaling both in PDAC cells and stromal cells. ${ }^{45,46}$ Thus, the Hh pathway plays a relevant role in determining the characteristic desmoplastic reaction of pancreatic neoplasms. ${ }^{47}$ Alternatively, pancreatic cancer cells that exhibit stem cell characteristics (e.g., self-renewal, ability to produce differentiated progeny, and resistance towards conventional chemo- and radiotherapy) exhibit an upregulation of $\mathrm{Hh}^{4}{ }^{48}$

Therefore, Hh inhibition can successfully target tumor growth, invasiveness, and the microenviroment. In preclinical models, Hh inhibitors increase chemotherapy delivery by depleting peritumoral stroma and increasing vascularity; thus, their combination with chemotherapy agents may be an attractive therapeutic strategy for PDAC. In recent years, the Hh pathway drug discovery efforts have been mainly focused on targeting SMO. Currently, investigated inhibitors of SMO include saridegib, vismodegib, and sonidegib. Saridegib abrogated the desmoplastic reaction, leading to increased delivery of chemotherapy in a murine model of pancreatic cancer. ${ }^{49}$ However, despite these encouraging results, the combination of saridegib and gemcitabine failed to reach the planned endpoint of a phase 2 clinical trial (NCT01130142). ${ }^{50}$ The combination of saridegib with a more intensive chemotherapy regimen (i.e., FOLFIRINOX) has also been explored. Preliminary results of this ongoing study showed that this combination has encouraging activity and manageable toxicity. ${ }^{51}$ Vismodegib, another Hh inhibitor, failed to show antitumor activity in a phase $1 \mathrm{~b}$ clinical trial in combination with gemcitabine, ${ }^{52}$ whereas the combination of vismodegib, gemcitabine, and nab-paclitaxel showed preliminary evidence of activity in an ongoing phase 2 trial. ${ }^{53}$ Finally, phase $1 / 2$ clinical trials of sonidegib (LDE225) in combination with gemcitabine and nabpaclitaxel (NCT01431794; NCT02358161) $)^{54,55}$ or phase 1 trials of sonidegib with gemcitabine alone (NCT01487785) ${ }^{56}$ or FOLFIRINOX ${ }^{57}$ are ongoing, and their results are eagerly awaited. Thus, targeting desmoplasia remains an attractive approach because it may affect drug delivery and inhibit PDAC progression.

\section{Hyaluronan Acid}

In physiological conditions, the amount of HA in extracellular matrix is controlled by a balance between its synthesis and degradation. ${ }^{58} \mathrm{HA}$ is abundantly produced in the surrounding stroma of malignant tumors, where it plays a role in tumor progression by enhancing cell proliferation, migration, invasion, metastasis, angiogenesis, and resistance to chemotherapeutic agents. In fact, HA overexpression may contribute to poor outcomes by reducing delivery of anticancer agents from the bloodstream. ${ }^{59}$ In preclinical models, the elimination of HA normalizes interstitial fluid pressure and increases vascular perfusion, thereby permitting drug delivery into neoplastic tissue. ${ }^{60}$ Human-recombinant PEGylated hyaluronidase (PEGPH20) represents an interesting approach to targeting pancreatic stroma by depleting HA that is abundant in the ECM of PDAC. ${ }^{61}$ In a phase $1 \mathrm{~b}$ study, patients with stage IV previously untreated PDAC were treated with PEGPH20 in combination with gemcitabine. A high response rate was reported in patients with elevated HA tumor staining, without major drug-related side effects. ${ }^{62}$ PEGPH20 is currently being investigated in other clinical trials in PDAC. In particular, the addition of PEGPH20 to standard chemotherapy regimens (e.g., the combination of gemcitabine and nab-paclitaxel or the FOLFIRINOX regimen) is under investigation (NCT01839487; NCT01959139). ${ }^{63,64}$

\section{Volume 5 Number $3-4$}




\section{Other Stroma Targets}

Other stroma-targeting compounds currently under evaluation include the combination of the heparin derivative ODSH (2-O,3-O desulfated heparin), a low-molecular-weight heparin that inhibits extracellular proteoglycans and growth factor receptors. ${ }^{65}$

Cationic liposomal paclitaxel (EndoTag-1) is paclitaxel embedded in cationic liposomes that enhance the compound affinity to negatively charged damaged tumor vessels. Results of a phase 2 trial ${ }^{66}$ comparing cationic liposomal paclitaxel plus gemcitabine versus gemcitabine alone were promising; however, these results should be confirmed in a phase 3 trial.

Finally, taking advantage of the hypoxic state of the tumor microenvironment, the use of prodrugs that must be activated under hypoxic environment to obtain better drug delivery could result in a tumortargeted treatment strategy. TH302, a prodrug of dibromo-isophosphamide mustard, an alkylating agent, is activated in hypoxic conditions. It has been evaluated in a randomized phase II trial with positive results in association with gemcitabine in PDAC patients. ${ }^{67}$ Interestingly, the combination treatment did not determine major toxicities compared to gemcitabine monotherapy.

\section{SUSTAINING PROLIFERATIVE SIGNALING}

Uncontrolled cell proliferation is recognized as one of the most fundamental traits of cancer cells and directly involves their capability to undergo uncontrolled growth irrespectively of tissue architecture and cell number homeostasis. ${ }^{68}$ In healthy tissues, proliferative signals are mainly provided by growth factors that bind cell-surface receptors, usually containing a catalytic tyrosine kinase domain that activates intracellular pathways to regulate cell cycle growth and apoptosis. ${ }^{69}$ Cancer cells may acquire their proliferative capability in different modalities: they may produce growth factor ligands themselves or they may stimulate tumor-associated stroma to produce growth factors useful for their proliferation and survival. Alternatively, cancer cells may undergo enhanced growth and proliferation overexpressing or producing abnormal growth factor receptors that generate a ligand independent signaling. Similarly, constitutively activated downstream mediators may confer growth autonomy to cancer cells. ${ }^{69}$

As for other neoplasms, abnormal cell proliferation is a common feature of pancreatic cancer cells. In PDAC, this event mainly involves the epidermal growth factor receptor (EGFR)-RAS/RAF/MEK/ ERK pathway that is abnormally activated in $>90 \%$ of preinvasive pancreatic lesions. ${ }^{70} \mathrm{On}$ the binding of key ligands (e.g., EGF or TGF- $\beta$ ), EGFR homo- or hetero-dimerizes with other members of the same receptor family, resulting in autophosphorylation of the intracellular receptor domain and recruitment of signaling complexes that activate a variety of downstream pathways, including PI3K/AKT/mTOR, STAT, and RAS-ERK, leading to uncontrolled cell proliferation. ${ }^{71}$ Other factors and membrane receptors under investigation as druggable targets include insulin-like growth factor (IGF), transforming growth factor $\beta$ (TGF- $\beta$ ), and hepatocyte growth factor receptor (HGFR). Currently, direct inhibition of these factors and receptors and their pathways is undergoing preclinical and clinical evaluations in PDAC.

\section{A. Epidermal Growth Factor Receptor}

As mentioned, EGFR is overexpressed in PDAC, and EGFR signaling is essential for $K-R A S$ mutant PDAC. ${ }^{72}$ Moreover, EGFR expression has been related to tumor aggressiveness, suggesting EGFR as a key promoter of PDAC development and a potential target for its treatment. ${ }^{73}$ Targeting EGFR in PDAC therapy has been investigated using different approaches: (1) tyrosine kinase inhibitors of the EGFR intracellular domain that block its activation and downstream signaling pathway recruitment or (2) monoclonal antibodies (MoAbs) that, binding the EGFR extracellular domain, prevent receptor dimerization and activation.

Erlotinib, a tyrosine kinase inhibitor (TKI) of HER-1/EGFR, has been intensively studied in PDAC. In a phase 3 trial, the combination of gemcitabine and erlotinib showed a minimal but statistically significant survival advantage compared with standard

Forum on Immunopathological Diseases and Therapeutics 
gemcitabine monotherapy (median OS 6.24 and 5.91 months in the experimental and in the control groups, respectively, $\mathrm{p}=.004) .{ }^{74} \mathrm{On}$ this basis, erlotinib was approved in metastatic PDAC, although its clinical utility is dismal due to the small survival benefit. Currently, given the relative success of adding nab-paclitaxel to gemcitabine and that of the FOLFIRINOX regimen, the role of erlotinib in PDAC is considered to have scanty relevance and no longer constitutes a standard of treatment for this disease. ${ }^{6,7}$

Cetuximab, a MoAb directed against the extracellular domain of EGFR, has been evaluated in metastatic PDAC. ${ }^{75}$ Despite promising initial results, the association of cetuximab to gemcitabine failed to obtain statistically significant results in a phase 3 clinical trial. ${ }^{76}$ Several explanations have been suggested; however, the constitutive activation of downstream elements such as K-RAS is reported as the most likely.

Other EGFR-targeted MoAbs under investigation in PDAC are nimotuzumab, matuzumab and panitumumab. Promising results have been reported in phase 2 studies. One of these included nimotuzumab in association with gemcitabine versus gemcitabine alone; ${ }^{77}$ another involved the dual blockade of EGFR by panitumumab and erlotinib in association with gemcitabine versus erlotinib and gemcitabine. ${ }^{78}$ Phase 3 trial results are awaited.

Strategies to enhance the antibody targeting of EGFR and consequently the clinical efficacy are currently being explored in preclinical pancreatic cancer models and include the possibility to combine two MoAbs recognizing distinct epitopes able to target the same ErbB protein. ${ }^{79}$

\section{B. Insulin-Like Growth Factor 1}

The insulin-like growth factor 1 (IGF-1) pathway is also expressed in the majority of PDACs and is involved in the activation of PI3-kinase/AKT/mTOR and MEK/ERK pathways. ${ }^{80}$ Cixutumumab, a MoAb against IGF-1, has been tested in a phase 2 clinical trial in combination with gemcitabine and erlotinib versus gemcitabine and erlotinib without evidence of efficacy advantages but with increased toxicity. ${ }^{81}$ In addition, the development of another IGF-1 MoAb, ganitumumab, has been stopped in PDAC due to negative results from a phase 3 trial. ${ }^{82}$

\section{Transforming Growth Factor- $\beta$}

Transforming growth factor- $\beta$ (TGF- $\beta$ ) is involved in epithelial-to-mesenchymal transition (EMT), invasion, and stroma-tumor dialogue and represents a potential therapeutic target in many tumors. ${ }^{83}$ TGF- $\beta$ is a commonly expressed signaling mediator in PDAC and represents one of the most commonly genetically altered pathways in this cancer, displaying a central role in the development of desmoplastic reaction. ${ }^{13}$ The inhibition of this pathway may be obtained through different approaches, such as (1) the inhibition of TGF- $\beta$ receptors, (2) ligand binding to the TGF- $\beta$ receptor by MoAbs, or (3) the inhibition of downstream signaling pathways by protein kinase inhibitors. The antisense oligonucleotide trabedersen (AP 12009) that specifically inhibits TGF- $\beta 2$ expression achieved promising results in a phase $1 / 2$ trial that included PDAC patients. ${ }^{84}$

\section{MET Proto-Oncogene Tyrosine Kinase Receptor}

MET, also called HGFR, is a membrane receptor with intrinsic tyrosine kinase activity that is essential for embryonic development and wound healing. It is abnormally expressed in PDAC and has an essential role in cell survival, growth, and the angiogenic switch. ${ }^{85}$ The MET inhibitor cabozantinib is currently under investigation in an ongoing phase 1 trial in PDAC patients (NCT01663272). ${ }^{86}$ Another MET inhibitor, tivantinib, that is currently undergoing intensive clinical investigation in several solid tumors showed promising results in in vitro PDAC models. ${ }^{87}$

\section{INDUCING ANGIOGENESIS}

Tumor invasion and progression requires sustenance of tumor cells with nutrients. The development of tumor-associated neovasculature provides tumor cells with nutrients and oxygen while it evacuates metabolic wastes and carbon dioxide. This leads to 
tumor growth and metastasis. Angiogenic switch is a major determinant of tumor development and causes normal vasculature to sprout new vessels that help neoplastic growth. ${ }^{88}$ Vascular endothelial growth factor (VEGF) and its receptors are promoters of tumor angiogenesis.

\section{A. Vascular Endothelial Growth Factor and Vascular Endothelial Growth Factor Receptor}

Despite a promising pharmacological rationale, the combination of gemcitabine plus the anti-VEGF $\mathrm{MoAb}$ bevacizumab failed to improve progressionfree survival (PFS) and OS in PDAC patients. ${ }^{89}$ Similarly, aflibercept, a MoAb that traps VEGF$\mathrm{A} / \mathrm{B}$ and placental growth factor, which is currently approved in metastatic colorectal cancer, did not improve OS when combined with gemcitabine in PDAC patients. ${ }^{90}$

The VEGF receptor (VEGFR) has been targeted with other drugs that block its activity. Axitinib, a TKI inhibitor of VEGFR1-3 and other receptors (PDGFR $\beta$ and c-Kit) that affects mainly tumor angiogenesis, showed no benefit when combined with gemcitabine compared to gemcitabine alone in a phase 3 trial. ${ }^{91}$ Similarly, sorafenib, a multikinase inhibitor of VEGFR1-3, PDGFR $\beta$, Kit, RET, and Raf-1, after promising results in xenograft models ${ }^{92}$ and in a phase I trial, ${ }^{93}$ failed to show a significant benefit when added to gemcitabine ${ }^{94}$ or to gemcitabine and cisplatin in phase 2 trials. ${ }^{95}$

In phase 2 trials, sunitinib, a multikinase inhibitor targeting VEGFR, did not show activity in advanced PDAC in monotherapy or in combination with gemcitabine ${ }^{96,97}$ However, sunitinib showed interesting results in PFS and disease stabilization when it was added as maintenance therapy after 6-months of standard gemcitabine chemotherapy. ${ }^{98}$ Thus, the role of the antiangiogenic therapy in PDAC remains unclear.

\section{EVADING GROWTH SUPPRESSORS}

Cell homeostasis is ensured by a multitude of negative feedback loops that normally cooperate to silence positive signals. Defects in these negative feedback mechanisms may enhance proliferative signals or may act as a positive signal themselves for cellular growth. Moreover, such mechanisms may also inhibit apoptosis. ${ }^{21}$

Among control loops of cellular homeostasis, the Kristen rat sarcoma (K-RAS) oncoprotein represents a key checkpoint stimulating downstream signaling pathways that drive many of the hallmarks of cancer such as sustained proliferation, metabolic reprogramming, anti-apoptosis, remodeling of the tumor microenvironment, evasion of the immune response, cell migration, and metastasis.

K-RAS is expressed as two isoforms (i.e., K-RAS4A, K-RAS4B) that, together with H-RAS and N-RAS isoforms, belong to the RAS monomeric small $\mathrm{G}$ protein family. K-RAS4B is the dominant isoform and is thought to be the major effector of the oncogenic activity ascribed to mutant $K-R A S .{ }^{99}$ In normal cells, RAS cycles between GTP-bound active and GDP-bound inactive states, by guanine nucleotide exchange factors (GEFs), which aid in the exchange of GDP for GTP. RAS activates the RAF/MEK/ERK signaling cascade, and RAS inactivation is mediated by GTP-ase-activating proteins (GAPs), which induce the hydrolysis of GTP. ${ }^{100} R A S$ oncogenic activating mutations are responsible for maintaining the protein in the GTP-bound form, thus, in a constitutively active form, independently from the stimulation of growth factors.

An analogous control loop involves a tensin homolog deleted on chromosome 10 phosphatase (PTEN). Its primary target is the phosphatidyl-inositol 3,4,5 triphosphate (PIP3), produced by phosphatidylinositol 3-kinase (PI3K). ${ }^{101}$ Loss of PTEN results in an accumulation of PIP3 that mimics the effect of PI3K activation and triggers the activation of its downstream effectors as AKT. The activation of the latter stimulates cell cycle progression, survival, metabolism, and migration through many subsequent pathways. ${ }^{101}$ AKT activity is therefore regulated by PI3K, which recruits AKT to the cell membrane, permitting its activation. AKT is also phosphorylated and activated by growth factors, including IGF1, increasing the complexity of this control loop. AKT also plays an important role in promoting cell sur-

Forum on Immunopathological Diseases and Therapeutics 
vival. ${ }^{102}$ Targeting these checkpoints is an intriguing challenge in the treatment of cancer, including PDAC.

\section{A. RAS-RAF-MEK-ERK Pathway}

Mutationally activated K-RAS results in active signaling of intracellular mitogenic pathways, including RAF-MEK-ERK, PI3K/Pdk1/AKT, and the Ral guanine nucleotide exchange factor pathway, even in absence of proper stimulatory signals. ${ }^{103}$ Activating mutations of $K-R A S$ found in human PDAC occur mainly as point mutations at codon G12 (98\%) and, to a far lesser extent, at codons G13 and Q61. They impair intrinsic GTPase activity of the K-RAS protein and can block the interaction between K-RAS and GAPs. This leads to constitutive activation of K-RAS and persistent stimulation of downstream signaling pathways. ${ }^{104,105}$

Targeting K-RAS and other molecules such as MEK-1 and -2 is an ongoing challenge in PDAC research; it is under evaluation by different approaches. ${ }^{106,107}$ Farnesyltransferase inhibitors, such as tipifarnib, block the prenylation step that is required for membrane localization of RAS proteins, providing a therapeutical option as supported by preclinical results. ${ }^{108}$ Unfortunately, tipifarnib was unsuccessful in a phase 3 PDAC clinical trial comparing its association with gemcitabine versus gemcitabine alone. ${ }^{109}$ Several reasons could explain these disappointing results. Some RAS family members may utilize other steps, such as geranylgeranylation for membrane localization. On this basis, a strategy involving the dual blockade of farnesyltransferase and geranylgeranyltransferase was suggested. Despite the strong rationale, this approach failed in clinical trials due to toxicity. ${ }^{8}$ Furthermore, it is unknown whether membrane binding is necessary for mutated RAS activity.

However, due to the relevance of K-RAS in pancreatic malignancies, other compounds are under investigation. The RAS inhibitor, salirasib (i.e., s-trans transfarnesylthiosalicylic acid, FTS) by competing with farnesylated RAS for binding to escort proteins called galectins, may block RAS localization to plasma membrane, resulting in a downregulation of this pathway. ${ }^{110}$ However, salirasib failed in a phase
2 clinical trial concerning $K-R A S$-mutated stage IIIB/ IV lung adenocarcinoma, ${ }^{111}$ and despite some activity in a phase 1 study in PDAC patients, no other clinical trial with salirasib is currently ongoing due to the discontinuation of its development. ${ }^{112}$

A novel compound named phospho-FTS (PFTS or DC-1016) showed increased inhibition of K-RAS and increased tumor suppression when compared with salirasib, and it effectively prevented PanIN formation in a transgenic mouse model. ${ }^{113} \mathrm{~K}-\mathrm{RAS}$ has also been targeted with a novel small interfering RNA (siRNA) delivery system termed 'local drug eluter' (LODER). In preclinical PDAC models, this approach showed promising activity. ${ }^{114}$ The results of a phase 1 trial of local delivery of G12D siRNA in the tumor region through endoscopic ultrasound, followed by chemotherapy administration with two different schedules (gemcitabine monotherapy or FOLFIRINOX regimen), showed no dose-limiting toxicities and disease stability in $100 \%$ of patients on imaging with a reduction of CA-19-9 in 64\% of cases. ${ }^{115}$ Results of a phase 2 trial with LODER in patients with unresectable, locally advanced, PDAC are awaited (NCT01676259). ${ }^{116}$

MEK inhibitors pimasertib (MSC1936369B) and refametinib (BAY-869766) are under investigation in many cancers including PDAC, but the available results of two phase 2 trials are controversial: pimasertib failed to meet the primary endpoint of PFS advantage in combination with gemcitabine monotherapy, ${ }^{117}$ whereas refametinib showed promising activity in the same setting. ${ }^{118}$ Interestingly, biomarker results of the study combining refametinib and gemcitabine were also reported. ${ }^{119}$ Sixty-five percent of the enrolled patients had K-RAS mutations (mainly $K-R A S$ G12D, G12V, and G12R). The most frequent co-occurring somatic mutations or amplifications were TP53, CDKN2A, and $c M Y C$. A trend toward improved response, median PFS, and OS in the wild-type $K-R A S$ subset was observed. Another MEK inhibitor, selumetinib, was investigated in gemcitabine refractory pancreatic cancers with no success. ${ }^{120}$

Resistance to MEK inhibitors may be a consequence of different escape mechanisms. For example, the pharmacological inhibition of MEK leads to 
enhanced signaling through EGFR independent of $K-R A S$ mutational status. To overcome this negative feedback loop, a therapeutic strategy of combined target inhibition of EGFR and MEK has been investigated in a phase 2 trial with erlotinib and selumetinib, with promising results. ${ }^{121}$ Moreover, K-RAS can activate a variety of pathways other than the RAS-RAF-MEK-ERK pathway, such as PI3K/AKT, making useless the inhibition of a single component (see section V.B.).

An interesting strategy, currently only being investigated in vitro, is represented by the combination of the multitarget inhibitor sorafenib (see section IV.A.) and vitamin $\mathrm{K} 1$ in pancreatic cell lines. Results showed elevated levels of activated c-Jun N-terminal kinase (JNK) and its substrates c-Jun and FasL, leading to cell growth inhibition and apoptosis. This effect involved both inhibition of the RAF/MEK/ERK pathway as well as activation of the JNK, c-Jun, and FasL apoptotic pathways. ${ }^{122}$

\section{B. PI3K/AKT/mTOR Pathway}

The PI3K/AKT/mTOR pathway plays an important role in cancer cells regulating survival, proliferation, differentiation, and metabolism. ${ }^{123}$ As mentioned, dual PI3K and MEK inhibition may result in a better blockade of RAS signaling downstream pathways. Combining MEK inhibitors with antagonists of PI3K/ AKT/mTOR pathway may also represent a promising strategy to overcome the occurrence of resistance. In vitro and in vivo studies support this hypothesis. ${ }^{124}$ In subcutaneous xenograft mouse models, the PI3K inhibitor pictilisib (GDC0941) exhibited low antitumor activity as monotherapy but enhanced the efficacy of the MEK inhibitor selumetinib when used in combination. ${ }^{124}$ Clinical trials with MEK inhibitors and antagonists of PI3K/AKT are ongoing in various cancers, including PDAC (NCT01337765, NCT01363232, NCT01155453). ${ }^{125-127}$ Unfortunately, despite effectiveness in pancreatic neuroendocrine neoplasms, the mTOR inhibitor everolimus ${ }^{128,129}$ failed in PDAC when administered to chemotherapy refractory patients.

The inhibition of $\mathrm{PI} 3 \mathrm{~K} / \mathrm{PKB} / \mathrm{mTOR}$, Stat3, and FKHR pathways, as well as inhibition of tumor growth has been shown in a human orthotopic primary pancreatic cancer xenograft using the integrin-linked kinase (ILK) QLT0254. An increase of gemcitabine-induced apoptosis has been also shown by adding such an inhibitor. ${ }^{130}$

\section{GENOME INSTABILITY}

Acquisition of multiple hallmarks of cancer mainly depends on the addition of genomic alterations in neoplastic cells. This confers a selective advantage to subclones of neoplastic cells and enables their outgrowth and dominance in the neoplastic environment, creating the basis for tumor progression. Therefore, a succession of chance acquisition of an enabling mutant genotype may promote clonal expansion of neoplastic cells. ${ }^{21}$ Some clonal expansion may be acquired by epigenetic mechanisms (e.g., DNA methylation and histone modifications) triggered by nonmutational changes. Some others are achieved through a direct breakdown of genome integrity. Surveillance systems normally monitor genome integrity and force genetically damaged cells into senescence or apoptosis. However, if such systems are damaged, integrity of genome is impaired, giving advantage for tumor progression. ${ }^{21}$ The most important mechanism for repair of DNA double-strand breaks is homologous recombination. Severe chromosomal aberrations that commonly lead to cell death are due to the blockage of this event. BRCA1 and -2 genes are frequently mutated in many cancers including PDAC. Because BRCA is a crucial component of intracellular homologous recombination, double-strand break repair is defective in affected cells. In contrast, both single strand and base excision repair are controlled by mechanisms independent of BRCA. Single-strand break repair definitively depends on poly-ADP-ribose polymerase (PARP), whereas the role of PARP in base excision repair is not fully understood. ${ }^{131,132}$

BRCA1/2 harbors particular therapeutic interest because homozygous mutant pancreatic cells are particularly sensitive to DNA cross-linking agents such as mitomycin $\mathrm{C}$ and cisplatin as well as PARP inhibitors. ${ }^{133}$

Forum on Immunopathological Diseases and Therapeutics 
Because PARP inhibitors trigger cell death in BRCA deficient cells, they have received attention in cancer therapy. In PDAC, some clinical trials are assessing the role of PARP inhibitors such as veliparib, rucaparib, alvocidib, and BMN 673. Veliparib in combination with a gemcitabine/ cisplatin (NCT01585805) (134 $^{134}$ FOLFOX regimen (NCT01489865) $)^{135}$ is undergoing phase 2 studies. Other PARP inhibitors are under earlier clinical evaluation (NCT01286987, NCT02042378, NCT00047307). ${ }^{136-138}$

\section{EVADING THE IMMUNE SYSTEM}

Immune surveillance constantly monitors cells and tissue and is responsible for recognizing and eliminating cancer cells at an early stage. Thus, when tumors are detectable they have already avoided the immune system that resulted in an inability to eradicate tumor cells or to limit their extent. Many theories have been suggested to explain this phenomenon. ${ }^{21,139}$ The incidence of some tumors (e.g., virus-associated cancer) is increased in immunocompromised individuals. Cancer cells may present a different immunogenic phenotype, which in turn may result in good or weak "immunoediting." "140 It has been suggested that during cancer growth, highly immunogenic clones are recognized and disrupted by immune cells, inducing a positive selection for weakly immunogenic clones, which in turn may grow up and proliferate and eluding the immune systems controls. More recently, immunosuppressive factors have been indicated as the main mechanism for immune evasion. Cancer cells may paralyze infiltrating cytotoxic cells by producing immunosuppressive factors. Moreover, the production of active immunosuppressive factors by inflammatory cells themselves and the recruitment of immunosuppressive immune cells may represent a fundamental mechanism by which tumors evade immune response or the immune system does not recognize cancer cells. ${ }^{21}$ Immunotherapy has been considered an ineffective strategy in cancer therapy for a long time. In recent years, a better understanding of the immune system checkpoints and blockade mechanisms, as well as the development of new immunomodulatory agents and MoAbs able to interfere with immune response, has opened a new scenario for immunotherapy in many tumors, including PDAC. ${ }^{141}$

Many approaches are currently being investigated in clinical trials; they differ according to the mechanism used to interact with the immune response.

\section{A. Immune Checkpoints}

Immune checkpoints are inhibitory pathways by which the immune system maintains self-tolerance and prevents the development of autoimmunity. ${ }^{142}$ Tumors exploit some immune checkpoint pathways, thus subverting antitumor immunity (mainly T-cell responses). Because most immune checkpoint pathways are initiated by ligand-receptor interactions, they can be blocked by MoAbs and inhibitory peptides or modulated using recombinant forms of ligands or receptors. ${ }^{143}$ This may drive effector immune responses and enhance the efficacy of tumor vaccines and immunotherapeutics.

Ipilimumab is a MoAb that targets cytotoxic T-lymphocyte antigen 4 (CTLA-4). Because CTLA-4 is normally expressed on the surface of $\mathrm{T}$ cells as a negative regulator of their function, ipilimumab releases $\mathrm{T}$ cells from this inhibitory mechanism, enabling the uninhibited $\mathrm{T}$ cells to exert their full potential in creating antitumor immunity. Ipilimumab was investigated as a monotherapy in a phase 2 trial in PDAC without success. ${ }^{144}$ Currently, it is being investigated in combination with gemcitabine in a phase 1 trial including only PDAC patients (NCT01473940). ${ }^{145}$ Results are not yet available.

Nivolumab, a fully human programmed death 1 (PD-1) ligand (PD-L1)-specific IgG4 (S228P) MoAb, inhibits the binding of PD-1, a T-cell coinhibitory receptor that is selectively expressed on many tumors and on cells within the tumor microenvironment in response to inflammatory stimuli. Blockade of the interaction between PD-1 and PD-L1 by nivolumab potentiates immune responses in vitro and mediates preclinical antitumor activity. It has been evaluated in a phase 1 trial of patients with selected advanced cancers, including PDAC. Unfortunately, this drug showed activity in cancers 
other than PDAC. ${ }^{146}$ Dual combination blockade of PD1 receptor by nivolumab and CTLA4 by ipilimumab is actually ongoing in patients with advanced or metastatic solid tumors, including pancreatic cancer (NCT01928394). ${ }^{147}$

\section{B. Enhancing Immune Response}

Cancer vaccines are designed to elicit an immune response against tumor. Several trials of vaccines, given alone or with other therapies, are currently enrolling patients with pancreatic cancer. HyperAcute-Pancreas (algenpantucel-L), an allogeneic pancreatic cancer vaccine composed of two genetically engineered human PDAC cell lines (HAPa-1 and HAPa-2), was evaluated in a phase 2 trial in addition to fluorouracil- and gemcitabine-based chemoradiotherapy as adjuvant treatment in PDAC patients. Results showed a trend toward prolonged disease-free survival. ${ }^{148}$ Algenpantucel is currently being investigated in a phase 3 trial (NCT 01836432). ${ }^{149}$

GVAX vaccine composed of two irradiated, granulocyte-macrophage colony-stimulating factor (GM-CSF)-secreting allogeneic PDA cell lines induces $\mathrm{T}$ cells against a broad array of PDAC antigens. CRS-207, live-attenuated Listeria monocytogenes expressing mesothelin, induces innate and adaptive immunity.

A phase 2 trial involving GVAX vaccine and CRS-207 alone or combined with low-dose cyclophoposphamide chemotherapy was investigated in previously treated metastatic PDAC patients. Active treatment resulted in increased survival with reduced toxicity. ${ }^{150}$

\section{Other Signaling Pathways Regulating the Immune Response}

Signaling through Notch receptors regulates the differentiation and function of many cell types, including immune cells. ${ }^{151} \mathrm{~A}$ MoAb against Notch 2 and Notch 3 receptors, tarextumab, has been recently designed as an orphan drug for the treatment of advanced PDAC by FDA. A randomized phase $1 / 2$ trial comparing gemcitabine and nab- paclitaxel with or without tarextumab is ongoing (NCT01647828). ${ }^{152}$

Ensituximab, a MoAb against human colorectal and pancreatic carcinoma-associated antigens (CPAAs), has potential immunomodulating and antitumor activities. It is currently being investigated in phase 1/2 clinical trials (NCT01040000, NCT01834235). ${ }^{153,154}$

\section{CONCLUSIONS}

PDAC is one of most lethal cancers worldwide. Despite the relevance of this disease, treatment options have been limited and patient survival has not substantially changed over several decades. In the last few years, however, molecular understanding of PDAC has dramatically improved. A better knowledge of the disease genetics and of the role of the stroma for cancer development and progression and as a barrier to the optimal delivery of chemotherapy has opened the way to new potential therapeutic targets for PDAC. Target discovery and novel drug development research is focusing on specific PDAC molecular hallmarks such as metabolic pathways, proliferative and survival signaling pathways, tumor microenvironment, and immunology. PDAC is driven by alterations of multiple genes involved in the above cellular pathways and processes. A small number of driver mutations is possibly sufficient for PDAC tumorigenesis. Among them, $K-R A S$ activating mutations are the most common, and targeting K-RAS as well as other control loops involved in the same pathway appears to be one of the most promising approaches in PDAC therapy. The combination of chemotherapy with novel targeted drugs as well as the combination of targeted agents are being explored. Drugs targeting stroma or the immune system are also offering therapeutic alternatives for PDAC.

While cytotoxic agents are currently the reference drugs for the treatment of PDAC, promising data in the preclinical setting as well as preliminary results from clinical trials, underscore the importance of identifying druggable targets within the molecular hallmarks of this cancer. 


\section{ACKNOWLEDGMENTS}

Supported by a grant from the Ente Cassa di Risparmio di Firenze (Florence, Italy), Istituto Toscano Tumori (Florence, Italy), and Associazione Giacomo Onlus (Castiglioncello - LI, Italy).

\section{REFERENCES}

1. Hamilton SR, Aaltonen LA, editors. WHO classification of tumors of the digestive system. Lyon: IARC Press, 2000:220.

2. International Agency for Research on Cancer, World Health Organization, Globocan 2012: Estimated cancer incidece, mortality and prevalence worldwide in 2012. http://globocan.iarc.fr

3. Cascinu S, Jelic S. Pancreatic cancer: ESMO clinical recommendations for diagnosis, treatment and follow-up. Ann Oncol. 2009;20(S4):iv37-iv40.

4. Oettle H, Neuhaus P, Hochhaus A Hartmann JT, Gellert K, Ridwelski K, Niedergethmann M, Zülke C, Fahlke J, Arning MB, Sinn M, Hinke A, Riess H. Adjuvant chemotherapy with gemcitabine and longterm outcomes among patients with resected pancreatic cancer the CONKO-001 randomized trial. JAMA. 2013;2010:1473-81.

5. Siegel RL, Miller KD, Jemal A. Cancer statistics, 2015. CA Cancer J Clin. 2015;65:5-29.

6. Conroy T, Desseigne F, Ychou M, Bouché O, Guimbaud R, Bécouarn Y, Adenis A, Raoul JL, Gourgou-Bourgade $\mathrm{S}$, de la Fouchardière $\mathrm{C}$, Bennouna $\mathrm{J}$, Bachet JB, Khemissa-Akouz F, Péré-Vergé D, Delbaldo C, Assenat E, Chauffert B, Michel P, Montoto-Grillot C, Ducreux M; Groupe Tumeurs Digestives of Unicancer; PRODIGE Intergroup. FOLFIRINOX versus gemcitabine for metastatic pancreatic cancer. N Engl J Med. 2011;364: $1817-25$.

7. Von Hoff DD, Ervin T, Arena FP, Chiorean EG, Infante J, Moore M, Seay T, Tjulandin SA, Ma WW, Saleh MN, Harris M, Reni M, Dowden S, Laheru D, Bahary N, Ramanathan RK, Tabernero J, Hidalgo M, Goldstein D, Van Cutsem E, Wei X, Iglesias J, Renschler MF. Increased survival in pancreatic cancer with nab-paclitaxel plus gemcitabine. N Engl J Med. 2013;369:1691-703.

8. Saif MW. Advanced stage pancreatic cancer: novel therapeutic options. Expert Rev Clin Pharmacol. 2014;7:487-98.

9. Burris HA 3rd, Moore MJ, Andersen J, Green MR, Rothenberg ML, Modiano MR, Cripps MC, Portenoy RK, Storniolo AM, Tarassoff P, Nelson R, Dorr FA, Stephens $\mathrm{CD}$, Von Hoff DD. Improvements in survival and clinical benefit with gemcitabine as first-line therapy for patients with advanced pancreas cancer: a randomized trial. J Clin Oncol. 1997;15:2403-13.

10. Permuth-Wey J, Egan KM. Family history is a significant risk factor for pancreatic cancer: results from a systematic review and meta-analysis. FamCancer. 2009;8:109-17.

11. Pancreatic Adenocarcinoma. NCCN Guidelines Version 1. 2015. Available from: http://www.nccn.org/professionals/ physician gls/f guidelines.asp.

12. Canto MI, Harinck F, Hruban RH, Offerhaus GJ, Poley JW, Kamel I, Nio Y, Schulick RS, Bassi C, Kluijt I, Levy MJ, Chak A, Fockens P, Goggins M, Bruno M; International Cancer of Pancreas Screening (CAPS) Consortium. International Cancer of the Pancreas Screening (CAPS) Consortium summit on the management of patients with increased risk for familial pancreatic cancer. Gut. 2013;62:339-47.

13. Jones S, Zhang X, Parsons DW, Lin JC, Leary RJ, Angenendt P, Mankoo P, Carter H, Kamiyama H, Jimeno A, Hong SM, Fu B, Lin MT, Calhoun ES, Kamiyama M, Walter K, Nikolskaya T, Nikolsky Y, Hartigan J, Smith DR, Hidalgo M, Leach SD, Klein AP, Jaffee EM, Goggins M, Maitra A, Iacobuzio-Donahue C, Eshleman JR, Kern SE, Hruban RH, Karchin R, Papadopoulos N, Parmigiani G, Vogelstein B, Velculescu VE, Kinzler KW. Core signaling pathways in human pancreatic cancers revealed by global genomic analyses. Science. 2008;321:1801-6.

14. Biankin AV, Waddell N, Kassahn KS, Gingras MC, Muthuswamy LB, Johns AL, Miller DK, Wilson PJ, Patch AM, Wu J, Chang DK, Cowley MJ, Gardiner BB, Song S, Harliwong I, Idrisoglu S, Nourse C, Nourbakhsh E, Manning S, Wani S, Gongora M, Pajic M, Scarlett CJ, Gill AJ, Pinho AV, Rooman I, Anderson M, Holmes O, Leonard C, Taylor D, Wood S, Xu Q, Nones K, Fink JL, Christ A, Bruxner T, Cloonan N, Kolle G, Newell F, Pinese M, Mead RS, Humphris JL, Kaplan W, Jones MD, Colvin EK, Nagrial AM, Humphrey ES, Chou A, Chin VT, Chantrill LA, Mawson A, Samra JS, Kench JG, Lovell JA, Daly RJ, Merrett ND, Toon C, Epari K, Nguyen NQ, Barbour A, Zeps N; Australian Pancreatic Cancer Genome Initiative, Kakkar N, Zhao F, Wu YQ, Wang M, Muzny DM, Fisher WE, Brunicardi FC, Hodges SE, Reid JG, Drummond J, Chang K, Han Y, Lewis LR, Dinh H, Buhay CJ, Beck T, Timms L, Sam M, Begley K, Brown A, Pai D, Panchal A, Buchner N, De Borja R, Denroche RE, Yung CK, Serra S, Onetto N, Mukhopadhyay D, Tsao MS, Shaw PA, Petersen GM, Gallinger S, Hruban RH, Maitra A, Iacobuzio-Donahue CA, Schulick RD, Wolfgang CL, Morgan RA, Lawlor RT, Capelli P, Corbo V, Scardoni M, Tortora G, Tempero MA, Mann KM, Jenkins NA, Perez-Mancera PA, Adams DJ, Largaespada DA, Wessels LF, Rust AG, Stein LD, Tuveson DA, Copeland NG, Musgrove EA, Scarpa A, Eshleman JR, Hudson TJ, Sutherland RL, Wheeler DA, Pearson JV, McPherson JD, Gibbs RA, Grimmond SM. Pancreatic cancer genomes reveal aberrations 
in axon guidance pathway genes. Nature. 2012;491: 399-405.

15. Vogelstein B, Papadopoulos N, Velculescu VE, Zhou S, Diaz LA Jr, Kinzler KW. Cancer genome landscapes. Science. 2013;339:1546-58.

16. Ryan DP, Hong TS, Bardeesy N. Pancreatic adenocarcinoma. N Engl J Med. 2014;371:1039-49.

17. Campbell PJ, Yachida S, Mudie LJ, Stephens PJ, Pleasance ED, Stebbings LA, Morsberger LA, Latimer C, McLaren S, Lin ML, McBride DJ, Varela I, Nik-Zainal SA, Leroy C, Jia M, Menzies A, Butler AP, Teague JW, Griffin CA, Burton J, Swerdlow H, Quail MA, Stratton MR, Iacobuzio-Donahue $\mathrm{C}$, Futreal PA. The patterns and dynamics of genomic instability in metastatic pancreatic cancer. Nature. 2010;467:1109-13.

18. Yachida S, Jones S, Bozic I, Antal T, Leary R, Fu B, Kamiyama M, Hruban RH, Eshleman JR, Nowak MA, Velculescu VE, Kinzler KW, Vogelstein B, IacobuzioDonahue CA. Distant metastasis occurs late during the genetic evolution of pancreatic cancer. Nature. 2010;467:1114-7.

19. Collisson EA, Sadanandam A, Olson P, Gibb WJ, Truitt M, Gu S, Cooc J, Weinkle J, Kim GE, Jakkula L, Feiler HS, Ko AH, Olshen AB, Danenberg KL, Tempero MA, Spellman PT, Hanahan D, Gray JW. Subtypes of pancreatic ductal adenocarcinoma and their differing responses to therapy. Nat Med. 2011;17:500-3.

20. Zhao Y, Adjei AA. Targeting oncogenic drivers. Prog Tumor Res. 2014;41:1-14.

21. Hanahan D, Weinberg RA. Hallmarks of cancer: the next generation. Cell. 2011;144:646-74.

22. McLornan DP, List A, Mufti GJ. Applying synthetic lethality for the selective targeting of cancer. N Engl J Med. 2014;371:1725-35.

23. Catalano V, Turdo A, Di Franco S, Dieli F, Todaro M, Stassi G. Tumor and its microenvironment: a synergistic interplay. Semin Cancer Biol. 2013;23:522-32.

24. Neesse A, Michl P, Frese KK, Feig C, Cook N, Jacobetz MA, Lolkema MP, Buchholz M, Olive KP, Gress TM, Tuveson DA. Stromal biology and therapy in pancreatic cancer. Gut. 2011;60:861-8.

25. Feig C, Gopinathan A, Neesse A, Chan DS, Cook N, Tuveson DA. The pancreas cancer microenvironment. Clin Cancer Res. 2012;18:4266-76.

26. Omary MB, Lugea A, Lowe AW, Pandol SJ. The pancreatic stellate cell: a star on the rise in pancreatic diseases. J Clin Invest. 2007;117:50-9.

27. Neesse A, Frese KK, Bapiro TE, Nakagawa T, Sternlicht MD, Seeley TW, Pilarsky C, Jodrell DI, Spong SM, Tuveson DA. CTGF antagonism with mAb FG-3019 enhances chemotherapy response without increasing drug delivery in murine ductal pancreas cancer. Proc Natl Acad Sci U S A. 2013;110:12325-30.

28. Erkan M, Michalski CW, Rieder S, Reiser-Erkan C, Abiatari I, Kolb A, Giese NA, Esposito I, Friess H, Kleeff
$\mathrm{J}$. The activated stroma index is a novel and independent prognostic marker in pancreatic ductal adenocarcinoma. Clin Gastroenterol Hepatol. 2008;6:1155-61.

29. Provenzano PP, Cuevas C, Chang AE, Goel VK, Von Hoff DD, Hingorani SR. Enzymatic targeting of the stroma ablates physical barriers to treatment of pancreatic ductal adenocarcinoma. Cancer Cell. 2012;21:418-29.

30. Yonezawa S, Asai T, Oku N. Effective tumor regression by anti-neovascular therapy in hypovascular orthotopic pancreatic tumor model. J Control Release. 2007;118:303-9.

31. Erkan M, Hausmann S, Michalski CW, Fingerle AA, Dobritz M, Kleeff J, Friess H. The role of stroma in pancreatic cancer: diagnostic and therapeutic implications. Nat Rev Gastroenterol Hepatol. 2012;9:454-67.

32. Chiodoni C, Colombo MP, Sangaletti S. Matricellular proteins: from homeostasis to inflammation, cancer, and metastasis. Cancer Metastasis Rev. 2010;29:295-307.

33. Bradshaw AD. Diverse biological functions of the SPARC family of proteins. Int J Biochem Cell Biol. 2012;44:480-8.

34. Rivera LB, Bradshaw AD, Brekken RA. The regulatory function of SPARC in vascular biology. Cell Mol Life Sci. 2011;68:3165-73.

35. Francki A, Bradshaw AD, Bassuk JA, Howe CC, Couser WG, Sage EH. SPARC regulates the expression of collagen type I and transforming growth factor-beta1 in mesangial cells. J Biol Chem. 1999;274:32145-52.

36. Infante JR, Matsubayashi H, Sato N, Tonascia J, Klein AP, Riall TA, Yeo C, Iacobuzio-Donahue C, Goggins M. Peritumoral fibroblast SPARC expression and patient outcome with resectable pancreatic adenocarcinoma. J Clin Oncol. 2007;25:319-25.

37. Von Hoff DD, Penny R, Shack S, Campbell E, Taverna D, Borad M, Love D, Trent J, Bittner. M. Frequency of potential therapeutic targets identified by immunochemistry (IHC) and DNA microarray (DMA) in tumors from patients who have progressed on multiple therapeutic agents. J Clin Oncol (Meeting Abstracts) 2006; vol. 24 no. 18 Suppl, Abstract 3071

38. Neesse A, Krug S, Gress TM, Tuveson DA, Michl P. Emerging concepts in pancreatic cancer medicine: targeting the tumor stroma. Onco Targets Ther. 2013;7:33-43.

39. Von Hoff DD, Ramanathan RK, Borad MJ, Laheru DA, Smith LS, Wood TE, Korn RL, Desai N, Trieu V, Iglesias JL, Zhang H, Soon-Shiong P, Shi T, Rajeshkumar NV, Maitra A, Hidalgo M. Gemcitabine plus nab-paclitaxel is an active regimen in patients with advanced pancreatic cancer: a phase I/II trial. J Clin Oncol. 2011;29:4548-54.

40. Hidalgo M, Plaza C, Illei P, Brachmann C, Heise C, Pierce D, Romano A, Wei X, López-Ríos F, Von Hoff DD. SPARC analysis in the phase III mpact trial of nabpaclitaxel (nab-p) plus gemcitabine (gem) vs gem alone for patients with metastatic pancreatic cancer (pc). Ann Oncol 2014;25(suppl 2):ii106. 
41. Varjosalo M, Taipale J. Hedgehog: functions and mechanisms. Genes Dev. 2008;22:2454-72.

42. Ingham PW, McMahon AP. Hedgehog signaling in animal development: paradigms and principles. Genes Dev. 2001;15:3059-87.

43. Thayer SP, di Magliano MP, Heiser PW, Nielsen CM, Roberts DJ, Lauwers GY, Qi YP, Gysin S, Fernández-del Castillo C, Yajnik V, Antoniu B, McMahon M, Warshaw AL, Hebrok M. Hedgehog is an early and late mediator of pancreatic cancer tumorigenesis. Nature. 2003;425:851-6.

44. Amakye D, Jagani Z, Dorsch M. Unraveling the therapeutic potential of the Hedgehog pathway in cancer. Nat Med. 2013 Nov;19(11):1410-22.

45. Yauch RL, Gould SE, Scales SJ, Tang T, Tian H, Ahn CP, Marshall D, Fu L, Januario T, Kallop D, Nannini-Pepe M, Kotkow K, Marsters JC, Rubin LL, de Sauvage FJ. A paracrine requirement for hedgehog signalling in cancer. Nature. 2008;455:406-10.

46. Onishi H, Katano M. Hedgehog signaling pathway as a new therapeutic target in pancreatic cancer. World J Gastroenterol. 2014;20:2335-42.

47. Bailey JM, Swanson BJ, Hamada T, Eggers JP, Singh PK, Caffery T, Ouellette MM, Hollingsworth MA. Sonic hedgehog promotes desmoplasia in pancreatic cancer. Clin Cancer Res. 2008;14:5995-6004.

48. Lee CJ, Dosch J, Simeone DM. Pancreatic cancer stem cells. J Clin Oncol. 2008;26:2806-12.

49. Olive KP, Jacobetz MA, Davidson CJ, Gopinathan A, McIntyre D, Honess D, Madhu B, Goldgraben MA, Caldwell ME, Allard D, Frese KK, Denicola G, Feig C, Combs C, Winter SP, Ireland-Zecchini H, Reichelt S, Howat WJ, Chang A, Dhara M, Wang L, Rückert F, Grützmann R, Pilarsky C, Izeradjene K, Hingorani SR, Huang P, Davies SE, Plunkett W, Egorin M, Hruban RH, Whitebread N, McGovern K, Adams J, IacobuzioDonahue C, Griffiths J, Tuveson DA. Inhibition of Hedgehog signaling enhances delivery of chemotherapy in a mouse model of pancreatic cancer. Science. 2009;324:1457-61.

50. A Study Evaluating IPI-926 in Combination With Gemcitabine in Patients With Metastatic Pancreatic Cancer. ClinicalTrials.gov Identifier: NCT01130142. Available from: https://clinicaltrials.gov/ct2/show/ NCT01130142.

51. Ko AH, Lo Conte NK, Kantoff E,. Ross RW, Trehu EG, Tempero MA, Kelley RK, Venook AP, Wu T, Kindler HL. A phase Ib trial of FOLFIRINOX plus saridegib, an oral hedgehog $(\mathrm{Hh})$ inhibitor, in pts with advanced pancreatic cancer (PDAC). J Clin Oncol (Meeting Abstract) 2012, vol. 30, Suppl; Abstract 3105.

52. Catenacci DVT, Bahary N, Nattam SR, de Wilton Marsh R, Wallace JA, Rajdev L, Cohen DJ, Sleckman BG, Lenz HJ, Stiff PJ, Thomas SP, Xu P, Henderson L, Horiba MN, Vannier M, Karrison T, Stadler WM, Kindler HL. Final analysis of a phase IB/ randomized phase II study of gemcitabine $(\mathrm{G})$ plus placebo $(\mathrm{P})$ or vismodegib (V), a hedgehog (Hh) pathway inhibitor, in patients ( pts) with metastatic pancreatic cancer (PC): A University of Chicago phase II consortium study. J Clin Oncol (Meeting Abstracts) 2013 vol. 31, Suppl, Abstract 4012.

53. De Jesus-Acosta A, O'Dwyer PJ, Ramanathan RK, Von Hoff DD, Maitra A, Rasheed Z, Zheng L, Rajeshkumar NV, Le DT, Hoering A, Bolejack V, Yabuuchi S, Laheru DA. A phase II study of vismodegib, a hedgehog (Hh) pathway inhibitor, combined with gemcitabine and nab-paclitaxel (nab-P) in patients (pts) with untreated metastatic pancreatic ductal adenocarcinoma (PDA). J Clin Oncol (Meeting Abstracts) 2014 vol. 32, Suppl 3; Abstract 257.

54. Gemcitabine + Nab-paclitaxel With LDE-225 (Hedgehog Inhibitor) as Neoadjuvant Therapy for Pancreatic Adenocarcinoma. ClinicalTrials.gov Identifier: NCT01431794. Available from: https://clinicaltrials. gov/ct2/show/NCT01431794.

55. Phase I/II Study of LDE225 With Gemcitabine and Nab-paclitaxel in Patients With Pancreatic Cancer. ClinicalTrials.gov Identifier: NCT02358161. Available from: https://www.clinicaltrials.gov/ct2/show/ NCT02358161.

56. Dose-escalation, and Safety Study of LDE225 and Gemcitabine in Locally Advanced or Metastatic Pancreatic Cancer Patients. ClinicalTrials.gov Identifier: NCT01487785. Available from: https://clinicaltrials.gov/ ct2/show/NCT01487785.

57. LDE225 with fluorouracil, leucovorin, oxaliplatin, and irinotecan for untreated advanced pancreatic cancer. ClinicalTrials.gov Identifier: NCT01485744. Available from: https://clinicaltrials.gov/ct2/show/NCT01485744.

58. Laurent TC1, Fraser JR. Hyaluronan. FASEB J. 1992;6:2397-404.

59. Sironen RK, Tammi M, Tammi R, Auvinen PK, Anttila M, Kosma VM. Hyaluronan in human malignancies. Exp Cell Res. 2011;317:383-91.

60. Thompson CB, Shepard HM, O'Connor PM, Kadhim S, Jiang P, Osgood RJ, Bookbinder LH, Li X, Sugarman BJ, Connor RJ, Nadjsombati S, Frost GI. Enzymatic depletion of tumor hyaluronan induces antitumor responses in preclinical animal models. Mol Cancer Ther. 2010;9:3052-64.

61. Cheng XB, Sato N, Kohi S, Yamaguchi K. Prognostic impact of hyaluronan and its regulators in pancreatic ductal adenocarcinoma. PLoS One. 2013;8:e80765.

62. Hingorani SR, Harris WP, Beck JT, Berdov BA, Wagner SA, Pshevlotsky EM, Tjulandin S, Gladkov O, Holcombe RF, Jiang P, Maneval DC, Zhu J, Devoe CE. A phase Ib study of gemcitabine plus PEGPH20 (pegylated recombinant human hyaluronidase) in patients with stage IV previously untreated pancreatic cancer. J Clin Oncol (Meeting Abstracts) 2013 vol. 31, Suppl; Abstract 4010 63. PEGPH20 Plus Nab-Paclitaxel Plus Gemcitabine 
compared with nab-paclitaxel plus gemcitabine in subjects with stage IV untreated pancreatic cancer (HALO109-202). ClinicalTrials.gov Identifier: NCT01839487. Available from: https://clinicaltrials.gov/ct2/show/ NCT01839487.

64. S1313, Combination chemotherapy with or without PEGPH20 in treating patients with newly diagnosed metastatic pancreatic cancer. ClinicalTrials.gov Identifier: NCT01959139. Available from: https://clinicaltrials.gov/ ct2/show/NCT01959139.

65. Casu B, Vlodavsky I, Sanderson RD. Non-anticoagulant heparins and inhibition of cancer. Pathophysiol Haemost Thromb. 2008;36:195-203.

66. Löhr JM, Haas SL, Bechstein WO, Bodoky G, Cwiertka K, Fischbach W, Fölsch UR, Jäger D, Osinsky D, Prausova J, Schmidt WE, Lutz MP; CT4001 Study Group. Cationic liposomal paclitaxel plus gemcitabine or gemcitabine alone in patients with advanced pancreatic cancer: a randomized controlled phase II trial. Ann Oncol. 2012;23:1214-22.

67. David P. Ryan, Shantan G. Reddy, Nathan Bahary, Hope Elizabeth Uronis, Darren Sigal, Allen Lee Cohn, William R. Schelman, Joe Stephenson, Clarence Eng, Mitesh J. Borad. TH-302 plus gemcitabine $(G+T)$ versus gemcitabine $(\mathrm{G})$ in patients with previously untreated advanced pancreatic cancer (PAC). J Clin Oncol (Meeting Abstracts) 2013 vol. 31, Suppl 4; Abstract 325.

68. Lemmon MA, Schlessinger J. Cell signaling by receptor tyrosine kinases. Cell. 2010;141:1117-34.

69. Witsch E, Sela M, Yarden Y. Roles for growth factors in cancer progression. Physiology (Bethesda). 2010;25: 85-101.

70. Kanda M, Matthaei H, Wu J, Hong SM, Yu J, Borges M, Hruban RH, Maitra A, Kinzler K, Vogelstein B, Goggins $\mathrm{M}$. Presence of somatic mutations in most early-stage pancreatic intraepithelial neoplasia. Gastroenterology. 2012;142:730-3.

71. Troiani T, Martinelli E, Capasso A, Morgillo F, Orditura M, De Vita F, Ciardiello F. Targeting EGFR in pancreatic cancer treatment. Curr Drug Targets. 2012;13:802-10.

72. Navas C, Hernández-Porras I, Schuhmacher AJ, Sibilia M, Guerra C, Barbacid M. EGF receptor signaling is essential for k-ras oncogene-driven pancreatic ductal adenocarcinoma. Cancer Cell. 2012;22:318-30.

73. Ueda S, Hatsuse K, Tsuda H, Ogata S, Kawarabayashi N, Takigawa T, Einama T, Morita D, Fukatsu K, Sugiura Y, Matsubara O, Mochizuki H. Potential crosstalk between insulin-like growth factor receptor type 1 and epidermal growth factor receptor in progression and metastasis of pancreatic cancer. Mod Pathol. 2006;19:788-96.

74. Moore MJ, Goldstein D, Hamm J, Figer A, Hecht JR, Gallinger S, Au HJ, Murawa P, Walde D, Wolff RA, Campos D, Lim R, Ding K, Clark G, VoskoglouNomikos T, Ptasynski M, Parulekar W; National Cancer Institute of Canada Clinical Trials Group. Erlotinib plus gemcitabine compared with gemcitabine alone in patients with advanced pancreatic cancer: a phase III trial of the National Cancer Institute of Canada Clinical Trials Group. J Clin Oncol. 2007;25:1960-6.

75. Xiong HQ, Rosenberg A, LoBuglio A, Schmidt W, Wolff RA, Deutsch J, Needle M, Abbruzzese JL. Cetuximab, a monoclonal antibody targeting the epidermal growth factor receptor, in combination with gemcitabine for advanced pancreatic cancer: a multicenter phase II Trial. J Clin Oncol. 2004;22:2610-6.

76. Philip PA, Benedetti J, Corless CL, Wong R, O'Reilly EM, Flynn PJ, Rowland KM, Atkins JN, Mirtsching BC, Rivkin SE, Khorana AA, Goldman B, Fenoglio-Preiser CM, Abbruzzese JL, Blanke CD. Phase III study comparing gemcitabine plus cetuximab versus gemcitabine in patients with advanced pancreatic adenocarcinoma: Southwest Oncology Group-directed intergroup trial S0205. J Clin Oncol. 2010;28:3605-10.

77. Strumberg D, Schultheis B, Ebert MP, Kerkhoff A, Hofheinz Rd, Behringer DM, Schmidt WE, Goker E, De Dosso S, Kneba M, Yalcin S, Overkamp F, Schlegel F, Dommach M, Rohrberg R, Steinmetz T, Reuter D, Bach F. Phase II, randomized, double-blind placebo-controlled trial of nimotuzumab plus gemcitabine compared with gemcitabine alone in patients (pts) with advanced pancreatic cancer (PC). J Clin Oncol (Meeting Abstracts) 2013 vol. 31, Suppl 4; Abstract 4009

78. Kim GP, Foster NR, Salim M, Flynn PJ, Moore DF, Zon R, Mowat RB, Wiesenfeld M, McCullough AE, Alberts SR. Randomized phase II trial of panitumumab $(P)$,erlotinib (E) and gemcitabine $(\mathrm{G})$ versus erlotinibgemcitabine in patients withuntreated, metastatic pancreatic adenocarcinoma. J Clin Oncol (Meeting Abstracts) 2011 vol. 29, Suppl 4: Abstract 238.

79. Maron R, Schechter B, Mancini M, Mahlknecht G, Yarden Y, Sela M. Inhibition of pancreatic carcinoma by homo- and heterocombinations of antibodies against EGF-receptor and its kin HER2/ErbB-2. Proc Natl Acad Sci USA. 2013;110:15389-94.

80. Rieder S, Michalski CW, Friess H, Kleeff J. Insulin-like growth factor signaling as a therapeutic target in pancreatic cancer. Anticancer Agents Med Chem. 2011;11:427-33.

81. Philip PA, Goldman B, Ramanathan RK, Lenz HJ, Lowy AM, Whitehead RP, Wakatsuki T, Iqbal S, Gaur R, Benedetti JK, Blanke CD. Dual blockade of epidermal growth factor receptor and insulin-like growth factor receptor-1 signaling in metastatic pancreatic cancer: phase Ib and randomized phase II trial of gemcitabine, erlotinib, and cixutumumab versus gemcitabine plus erlotinib (SWOG S0727). Cancer. 2014;120:2980-5.

82. Fuchs CS, Ikeda M, Bodoky G, Okusaka T, Ohkawa S, Mizuno N, Swieboda-Sadlej A, Sobrero AF, Haddad $\mathrm{V}$, McGreivy JS. A phase III trial of ganitumab (GAN, AMG 479) with gemcitabine (G) as first-line treatment (tx) in patients (pts) with metastatic pancreatic cancer 
(MPC): An analysis of safety from the GAMMA trial (GEM and AMG 479 in Metastatic Adenocarcinoma of the Pancreas). J Clin Oncol (Meeting Abstracts) 2012 vol. 30, Suppl; Abstract 4042.

83. Massagué J. TGFbeta in Cancer. Cell. 2008;134:215-30.

84. Oettle H, Hilbig A, Seufferlein T, Tsianakas A, Luger T, Schmid RM, von Wichert G, Endlicher E, Garbe C, Kaehler KK, Hauschild A, Enk A, Kiessling P, Schmaus S, Heinrichs H, Schlingensiepen, K. Phase I/II study with trabedersen (AP 12009) monotherapy for the treatment of patients with advanced pancreatic cancer, malignant melanoma, and colorectal carcinoma. J Clin Oncol (Meeting Abstracts) 2011 vol. 29, Suppl; Abstract 2513.

85. Gherardi E, Birchmeier W, Birchmeier C, Vande Woude G. Targeting MET in cancer: rationale and progress. Nat Rev Cancer. 2012;12:89-103.

86. A Trial of Cabozantinib (XL184) and Gemcitabine in Advanced Pancreatic Cancer. ClinicalTrials.gov Identifier: NCT01663272. Available from: https://clinicaltrials.gov/ ct2/show/NCT01663272.

87. Rolfo CD, Avan A, Leon LG, Castiglia M, Honeywell R, Pauwels P, Peeters M, Peters G, Giovannetti E. Tivantinib-gemcitabine: pharmacological rational for a new combination in pancreatic cancer. Ann Oncol (Abstract Meeting) 2014 vol. 25, Suppl 4; Abstract 474P.

88. Hanahan D, Folkman J. Patterns and emerging mechanisms of the angiogenic switch during tumorigenesis. Cell. 1996;86:353-64.

89. Kindler HL, Niedzwiecki D, Hollis D, Sutherland S, Schrag D, Hurwitz H, Innocenti F, Mulcahy MF, O'Reilly E, Wozniak TF, Picus J, Bhargava P, Mayer RJ, Schilsky RL, Goldberg RM. Gemcitabine plus bevacizumab compared with gemcitabine plus placebo in patients with advanced pancreatic cancer: phase III trial of the Cancer and Leukemia Group B (CALGB 80303). J Clin Oncol. 2010;28:3617-22.

90. Rougier P, Riess H, Manges R, Karasek P, Humblet Y, Barone C, Santoro A, Assadourian S, Hatteville L, Philip PA. Randomised, placebo-controlled, double-blind, parallel-group phase III study evaluating aflibercept in patients receiving first-line treatment with gemcitabine for metastatic pancreatic cancer. Eur J Cancer. 2013;49:2633-4.

91. Kindler HL, Ioka T, Richel DJ, Bennouna J, Létourneau R, Okusaka T, Funakoshi A, Furuse J, Park YS, Ohkawa S, Springett GM, Wasan HS, Trask PC, Bycott P, Ricart $\mathrm{AD}$, Kim S, Van Cutsem E. Axitinib plus gemcitabine versus placebo plus gemcitabine in patients with advanced pancreatic adenocarcinoma: a double-blind randomised phase 3 study. Lancet Oncol. 2011;12:256-62.

92. Ulivi P, Arienti C, Zoli W, Scarsella M, Carloni S, Fabbri F, Tesei A, Chiadini E, Orlandi A, Passeri D, Zupi G, Milandri C, Silvestrini R, Amadori D, Leonetti C. In vitro and in vivo antitumor efficacy of docetaxel and sorafenib combination in human pancreatic cancer cells. Curr Cancer Drug Targets. 2010;10:600-10.

93. Siu LL, Awada A, Takimoto CH, Piccart M, Schwartz B, Giannaris T, Lathia C, Petrenciuc O, Moore MJ. Phase I trial of sorafenib and gemcitabine in advanced solid tumors with an expanded cohort in advanced pancreatic cancer. Clin Cancer Res. 2006;12:144-51.

94. Kindler HL, Wroblewski K, Wallace JA, Hall MJ, Locker G, Nattam S, Agamah E, Stadler WM, Vokes EE. Gemcitabine plus sorafenib in patients with advanced pancreatic cancer: a phase II trial of the University of Chicago Phase II Consortium. Invest New Drugs. 2012;30:382-6.

95. Cascinu S, Berardi R, Sobrero A, Bidoli P, Labianca R, Siena S, Ferrari D, Barni S, Aitini E, Zagonel V, Caprioni F, Villa F, Mosconi S, Faloppi L, Tonini G, Boni C, Conte P, Di Costanzo F, Cinquini M; Italian Group for the Study of Digestive Tract Cancer (GISCAD). Sorafenib does not improve efficacy of chemotherapy in advanced pancreatic cancer: A GISCAD randomized phase II study. Dig Liver Dis. 2014;46:182-6.

96. O’Reilly EM, Niedzwiecki D, Hall M, Hollis D, BekaiiSaab T, Pluard T, Douglas K, Abou-Alfa GK, Kindler HL, Schilsky RL, Goldberg RM; Cancer and Leukemia Group B. A Cancer and Leukemia Group B phase II study of sunitinib malate in patients with previously treated metastatic pancreatic adenocarcinoma (CALGB 80603). Oncologist. 2010;15:1310-9.

97. Richly H, Maute L, Heil G, Rüssel J, Jäger E, Koeberle D, Fuxius S, Weigang-Koehler K, Aulitzky W, Woehrmann B, Hartung GG, Moritz B, Burkholder I, Scheulen ME, Bergmann L. Prospective randomized phase II trial with gemcitabine versus gemcitabine plus sunitinib in advanced pancreatic cancer: a study of the CESAR Central European Society for Anticancer Drug Research-EWIV. J Clin Oncol (Meeting Abstract) 2013 vol. 31, Suppl; Abstract 4035.

98. Reni M, Cereda S, Milella M, Novarino A, Passardi A, Mambrini A, Di Lucca G, Aprile G, Belli C, Danova M, Bergamo F, Franceschi E, Fugazza C, Ceraulo D, Villa E. Maintenance sunitinib or observation in metastatic pancreatic adenocarcinoma: a phase II randomised trial. Eur J Cancer. 2013;49:3609-15.

99. Jancík S, Drábek J, Radzioch D, Hajdúch M. Clinical relevance of KRAS in human cancers. J Biomed Biotechnol. 2010; doi:10.1155/2010/150960.

100. Pylayeva-Gupta Y, Grabocka E, Bar-Sagi D. RAS oncogenes: weaving a tumorigenic web. Nat Rev Cancer. 2011;11:761-74.

101. Maehama T, Dixon JE. The tumor suppressor, PTEN/ MMAC1, dephosphorylates the lipid second messenger, phosphatidylinositol 3,4,5-trisphosphate. J Biol Chem. 1998;273:13375-8.

102. Vivanco I, Sawyers CL. The phosphatidylinositol 3-Kinase AKT pathway in human cancer. Nat Rev Cancer. 2002;2:489-501. 
103. Belda-Iniesta C, Ibáñez de Cáceres I, Barriuso J, de Castro Carpeño J, González Barón M, Feliú J. Molecular biology of pancreatic cancer. Clin Transl Oncol. 2008;10:530-7.

104. Eser S, Schnieke A, Schneider G, Saur D. Oncogenic KRAS signalling in pancreatic cancer. $\mathrm{Br} \mathrm{J}$ Cancer. 2014;111:817-22.

105. Morris JP 4th, Wang SC, Hebrok M. KRAS, Hedgehog, Wnt and the twisted developmental biology of pancreatic ductal adenocarcinoma. Nat Rev Cancer. 2010;10:683-95.

106. Neuzillet C, Hammel P, Tijeras-Raballand A, Couvelard A, Raymond E. Targeting the Ras-ERK pathway in pancreatic adenocarcinoma. Cancer Metastasis Rev. 2013;32:147-62.

107. Rowinsky EK, Windle JJ, Von Hoff DD. Ras protein farnesyltransferase: A strategic target for anticancer therapeutic development. J Clin Oncol. 1999;17:3631-52.

108. End DW, Smets G, Todd AV, Applegate TL, Fuery CJ, Angibaud P, Venet M, Sanz G, Poignet H, Skrzat S, Devine A, Wouters W, Bowden C. Characterization of the antitumor effects of the selective farnesyl protein transferase inhibitor R115777 in vivo and in vitro. Cancer Res. 2001;61:131-7.

109. Van Cutsem E, van de Velde H, Karasek P, Oettle H, Vervenne WL, Szawlowski A, Schoffski P, Post S, Verslype C, Neumann H, Safran H, Humblet Y, Perez Ruixo J, Ma Y, Von Hoff D. Phase III trial of gemcitabine plus tipifarnib compared with gemcitabine plus placebo in advanced pancreatic cancer. J Clin Oncol. 2004;22:1430-8.

110. Rotblat B, Ehrlich M, Haklai R, Kloog Y. The Ras inhibitor farnesylthiosalicylic acid (Salirasib) disrupts the spatiotemporal localization of active Ras: a potential treatment for cancer. Methods Enzymol. 2008;439:467-89.

111. Riely GJ, Johnson ML, Medina C, Rizvi NA, Miller VA, Kris MG, Pietanza MC, Azzoli CG, Krug LM, Pao W, Ginsberg MS. A phase II trial of Salirasib in patients with lung adenocarcinomas with KRAS mutations. J Thorac Oncol. 2011;6:1435-7.

112. Laheru D, Shah P, Rajeshkumar NV, McAllister F, Taylor G, Goldsweig H, Le DT, Donehower R, Jimeno A, Linden S, Zhao M, Song D, Rudek MA, Hidalgo M. Integrated preclinical and clinical development of S-trans, transFarnesylthiosalicylic Acid (FTS, Salirasib) in pancreatic cancer. Invest New Drugs. 2012;30:2391-9.

113. Mackenzie GG, Bartels LE, Xie G, Papayannis I, Alston N, Vrankova K, Ouyang N, Rigas B. A novel Ras inhibitor (MDC-1016) reduces human pancreatic tumor growth in mice. Neoplasia. 2013;15:1184-95.

114. Zorde Khvalevsky E, Gabai R, Rachmut IH, Horwitz E, Brunschwig Z, Orbach A, Shemi A, Golan T, Domb AJ, Yavin E, Giladi H, Rivkin L, Simerzin A, Eliakim R, Khalaileh A, Hubert A, Lahav M, Kopelman Y, Goldin E, Dancour A, Hants Y, Arbel-Alon S, Abramovitch $\mathrm{R}$, Shemi A, Galun E. Mutant KRAS is a druggable target for pancreatic cancer. Proc Natl Acad Sci USA. 2013;110:20723-8.
115. Golan T, Hubert A, Shemi A, Segal A, Dancour A, Khvalevsky EZ, Ben-David E, Raskin S, Goldes Y, Inbar Y, Lahav M, Domb A, Galun E. A phase I trial of a local delivery of siRNA against k-ras in combination with chemotherapy for locally advanced pancreatic adenocarcinoma. J Clin Oncol (Meeting Abstract) 2013, vol. 31, Suppl; Abstract 4037.

116. A Phase II Study of siG12D LODER in Combination With Chemotherapy in Patients With Unresectable Locally Advanced Pancreatic Cancer. ClinicalTrials.gov Identifier: NCT01676259. Available from: https://clinicaltrials.gov/ ct2/show/NCT01676259.

117. Van Cutsem E, Hidalgo M, Bazin I, Canon JL, Poddubskaya E, Manojlovic N, Milella M, Radenkovic D, Verslype C, Guo W, Damstrup L, Hammel P. Phase II randomized trial of MEK inhibitor pimasertib or placebo combined with gemcitabine in the first-line treatment of metastatic pancreatic cancer. 2015 Gastrointestinal Cancers Symposium. J Clin Oncol (Meeting Abstract) 2015, vol. 33, Suppl 3; Abstract 344.

118. Van Laethem JL, Jassem J, Heinemann V, Weekes CD, Bridgewater JA, Cascinu S, Melichar B, Peeters M, Ross PJ, Saramak P, Giurescu M, Garosi VL, Roth K, Schulz A, Teufel M, Childs BH, Riess H. Phase II study of refametinib (BAY 86-9766), an allosteric dual MEK 1/2 inhibitor, and gemcitabine in patients with unresectable, locally advanced, or metastatic pancreatic cancer. J Clin Oncol (Meeting Abstract) 2014, vol. 32, Suppl; Abstract 4025.

119. Riess H, Van Laethem JL, Martens Um, Heinemann V, Michl P, Peeters M, Van Brummelen D, Weekes CD, Dueland S, Schmiegel WH, Giurescu M, Garosi VL, Schulz A, Seidel H, Childs BH, Teufel M. Phase II study of the MEK inhibitor refametinib (BAY 869766) in combination with gemcitabine in patients with unresectable, locally advanced, or metastatic pancreatic cancer: Biomarker results. J Clin Oncol (Meeting Abstract) 2014, vol. 32, Suppl; Abstract 4025.

120. Bodoky G, Timcheva C, Spigel DR, La Stella PJ, Ciuleanu TE, Pover G, Tebbutt NC. A phase II openlabel randomized study to assess the efficacy and safety of selumetinib (AZD6244 [ARRY-142886]) versus capecitabine in patients with advanced or metastatic pancreatic cancer who have failed first-line gemcitabine therapy. Invest New Drugs. 2012 Jun;30(3):1216-23. doi: 10.1007/s10637-011-9687-4. Epub 2011 May 19. Erratum in: Invest New Drugs. 2012;30:1272-3.

121. Ko AH, Tempero MA, Bekaii-Saab TB, Kuhn P, Courtin R, Ziyeh S, Tahiri S, Kelley KR, Dito E, Ong A, Linetskaya R, Mirzoeva OK, Wu CSY, Venook AP, Korn WM. Helen Diller Family Comprehensive Cancer Center, University of California, San Francisco, San Francisco, CA; Helen Diller Family Comprehensive Cancer Center, University of California San Francisco, San Francisco, CA; Ohio State University Comprehensive Cancer Center, Columbus, 
OH; The Scripps Research Institute, La Jolla, CA. Dual MEK/EGFR inhibition for advanced, chemotherapyrefractory pancreatic cancer: A multicenter phase II trial of selumetinib (AZD6244; ARRY-142886) plus erlotinib. J Clin Oncol (Meeting Abstract) 2013, vol. 31, Suppl; Abstract 4014.

122. Wei G, Wang M, Carr BI. Sorafenib combined vitamin K induces apoptosis in human pancreatic cancer cell lines through RAF/MEK/ERK and c-Jun NH2-terminal kinase pathways. J Cell Physiol. 2010;224:112-9.

123. Polivka J Jr, Janku F. Molecular targets for cancer therapy in the PI3K/AKT/mTOR pathway. Pharmacol Ther. 2014;142:164-75.

124. Zhong H, Sanchez C, Spitrzer D, Plambeck-Suess S, Gibbs J, Hawkins WG, Denardo D, Gao F, Pufahl RA, Lockhart AC, Xu M, Linehan D, Weber J, Wang-Gillam A. Synergistic effects of concurrent blockade of PI3K and MEK pathways in pancreatic cancer preclinical models. PLoS One. 2013;8:e77243.

125. Safety, pharmacokinetics and pharmacodynamics of BEZ235 Plus MEK162 in selected advanced solid tumor patients. ClinicalTrials.gov Identifier: NCT01337765. Available from: https://clinicaltrials.gov/ct2/show/ NCT01337765.

126. Safety, pharmacokinetics and pharmacodynamics of BKM120 plus MEK162 in selected advanced solid tumor patients. ClinicalTrials.gov Identifier: NCT01363232. Available from: https://clinicaltrials.gov/ct2/show/ NCT01363232.

127. A study to investigate safety, pharmacokinetics (PK) and pharmacodynamics (PD) of BKM120 Plus GSK1120212 in selected advanced solid tumor patients. ClinicalTrials. gov Identifier: NCT01155453. https://clinicaltrials.gov/ ct2/show/NCT01155453.

128. Wolpin BM, Hezel AF, Abrams T, Blaszkowsky LS, Meyerhardt JA, Chan JA, Enzinger PC, Allen B, Clark JW, Ryan DP, Fuchs CS. Oral mTOR inhibitor everolimus in patients with gemcitabine-refractory metastatic pancreatic cancer. J Clin Oncol. 2009;27:193-8.

129. Javle MM, Shroff RT, Xiong H, Varadhachary GA, Fogelman D, Reddy SA, Davis D, Zhang Y, Wolff RA, Abbruzzese JL. Inhibition of the mammalian target of rapamycin (mTOR) in advanced pancreatic cancer: results of two phase II studies. BMC Cancer. 2010;10:368.

130. Yau CY, Wheeler JJ, Sutton KL, Hedley DW. Inhibition of integrin-linked kinase by a selective small molecule inhibitor, QLT0254, inhibits the PI3K/PKB/mTOR, Stat3, and FKHR pathways and tumor growth, and enhances gemcitabine-induced apoptosis in human orthotopic primary pancreatic cancer xenografts. Cancer Res. 2005;65:1497-504.

131. Pears CJ, Couto CA, Wang HY, Borer C, Kiely R, Lakin ND. The role of ADP-ribosylation in regulating DNA double-strand break repair. Cell Cycle. 2012;11:48-56.

132. De Vos M, Schreiber V, Dantzer F. The diverse roles and clinical relevance of PARPs in DNA damage repair: current state of the art. Biochem Pharmacol. 2012;84:137-46.

133. Chalasani P, Kurtin S, Dragovich T. Response to a third-line mitomycin C (MMC)-based chemotherapy in a patient with metastatic pancreatic adenocarcinoma carrying germline BRCA2 mutation. JOP. 2008;9:305-8.

134. Gemcitabine hydrochloride and cisplatin with or without veliparib or veliparib alone in patients with locally advanced or metastatic pancreatic cancer. ClinicalTrials. gov Identifier: NCT01585805. Available from: https:// clinicaltrials.gov/ct2/show/NCT01585805.

135. ABT-888 with modified FOLFOX6 in patients with metastatic pancreatic cancer. ClinicalTrials.gov Identifier: NCT01489865. Available from: https://clinicaltrials.gov/ ct2/show/NCT01489865.

136. Study of BMN 673, a PARP inhibitor, in patients with advanced or recurrent solid tumors. ClinicalTrials. gov Identifier: NCT01286987. Available from: https:// clinicaltrials.gov/ct2/show/NCT01286987.

137. A study of rucaparib in patients with pancreatic cancer and a known deleterious BRCA mutation. ClinicalTrials.gov Identifier: NCT02042378. Available from: https://www. clinicaltrials.gov/ct2/show/NCT02042378.

138. Flavopiridol plus radiation therapy followed by gemcitabine hydrochloride in treating patients with locally advanced, unresectable pancreatic cancer. ClinicalTrials. gov Identifier: NCT00047307. Available from: https:// clinicaltrials.gov/ct2/show/NCT00047307.

139. Bhatia A1, Kumar Y. Cellular and molecular mechanisms in cancer immune escape: a comprehensive review. Expert Rev Clin Immunol. 2014;10:41-62.

140. Kim R, Emi M, Tanabe K. Cancer immunoediting from immune surveillance to immune escape. Immunology. 2007;121:1-14.

141. Sideras K, Braat H, Kwekkeboom J, van Eijck CH, Peppelenbosch MP, Sleijfer S, Bruno M. Role of the immune system in pancreatic cancer progression and immune modulating treatment strategies. Cancer Treat Rev. 2014;40:513-22.

142. Pardoll DM. The blockade of immune checkpoints in cancer immunotherapy. Nat Rev Cancer. 2012;12:252-64.

143. Butt AQ, Mills KH. Immunosuppressive networks and checkpoints controlling antitumor immunity and their blockade in the development of cancer immunotherapeutics and vaccines. Oncogene. 2014;33:4623-31.

144. Royal RE, Levy C, Turner K, Mathur A, Hughes M, Kammula US, Sherry RM, Topalian SL, Yang JC, Lowy I, Rosenberg SA. Phase 2 trial of single agent Ipilimumab (anti-CTLA-4) for locally advanced or metastatic pancreatic adenocarcinoma. J Immunother. 2010;33:828-33.

145. Ipilimumab and gemcitabine hydrochloride in treating patients with stage III-IV or recurrent pancreatic cancer that cannot be removed by surgery. ClinicalTrials. 
gov Identifier: NCT01473940. Available from: https:/ clinicaltrials.gov/ct2/show/NCT01473940.

146. Brahmer JR, Tykodi SS, Chow LQ, Hwu WJ, Topalian SL, Hwu P, Drake CG, Camacho LH, Kauh J, Odunsi K, Pitot HC, Hamid O, Bhatia S, Martins R, Eaton K, Chen S, Salay TM, Alaparthy S, Grosso JF, Korman AJ, Parker SM, Agrawal S, Goldberg SM, Pardoll DM, Gupta A, Wigginton JM. Safety and activity of anti-PD-L1 antibody in patients with advanced cancer. N Engl J Med. 2012;366:2455-65.

147. A phase 1/2, open-label study of nivolumab monotherapy or nivolumab combined with ipilimumab in subjects with advanced or metastatic solid tumors. ClinicalTrials.gov Identifier: NCT01928394. Available from: ClinicalTrials. gov Identifier: NCT01928394.

148. Hardacre JM, Mulcahy M, Small W, Talamonti M, Obel J, Krishnamurthi S, Rocha-Lima CS, Safran H, Lenz HJ, Chiorean EG. Addition of algenpantucel-L immunotherapy to standard adjuvant therapy for pancreatic cancer: a phase 2 study. J Gastrointest Surg. 2013;17:94-100.

149. Immunotherapy study in borderline resectable or locally advanced unresectable pancreatic cancer (PILLAR). ClinicalTrials.gov Identifier: NCT01836432. Available from: https://clinicaltrials.gov/ct2/show/ NCT01836432.
150. Le DT, Wang-Gillam A, Picozzi V, Greten TF, Crocenzi T, Springett G, Morse M, Zeh H, Cohen D, Fine RL, Onners B, Uram JN, Laheru DA, Lutz ER, Solt S, Murphy AL, Skoble J, Lemmens E, Grous J, Dubensky T Jr, Brockstedt DG, Jaffee EM. Safety and survival with GVAX pancreas prime and listeria monocytogenes-expressing mesothelin (CRS-207) boost vaccines for metastatic pancreatic cancer. J Clin Oncol. 2015;pii: JCO.2014.57.4244.

151. Radtke F, MacDonald HR, Tacchini-Cottier F. Regulation of innate and adaptive immunity by Notch. Nat Rev Immunol. 2013;13:427-37.

152. A Phase $1 \mathrm{~b} / 2$ Study of OMP-59R 5 in combination with nab-paclitaxel and gemcitabine in subjects with previously untreated stage IV pancreatic cancer (ALPINE). ClinicalTrials.gov Identifier: NCT01647828. Available from: https://clinicaltrials.gov/ct2/show/NCT01647828.

153. Phase 2 study of NPC-1C chimeric monoclonal antibody to treat pancreatic and colorectal cancer. ClinicalTrials. gov Identifier: NCT01040000. Available from: https:// clinicaltrials.gov/ct2/show/NCT01040000.

154. A study of gemcitabine and Nab-paclitaxel with or without NPC-1C to treat patients with pancreatic cancer. ClinicalTrials.gov Identifier: NCT01834235. Available from: https://www.clinicaltrials.gov/ct2/show/ NCT01834235. 